\title{
Youth Religiosity and Da'wah Development at the Class II LPKA Rutan Sukamiskin Bandung
}

\author{
Hikmat Hikmat ${ }^{{ }^{*}}$ \\ ${ }^{1}$ UIN Sunan Gunung Djati Bandung \\ *email.hikmat@uinsgd.ac.id
}

\begin{abstract}
The purpose of this study is to get empirical data on the level of adolescent religiosity of assisted residents in Rutan LPKA Class II Sukamiskin Bandung. Second, to get data about the development of dakwah and religious guidance for young people assisted in Class II Sukamiskin LPKA Rutan, Bandung. This study uses the Research and Development (R\&D) method or research and development with a qualitative approach. The results showed that the religiosity of the assisted residents at the LPKA Prison was categorized into three: the level of religion was excellent, good enough, and less, of the three categories, determined the da'wah program and spiritual development at the LPKA Sukamiskin Bandung youth detention center. The development of da'wah and patterns of religious guidance for youth assisted residents at Class II Sukamisnin Rutan LPKA Bandung was carried out by involving various parties. As an institution, in collaboration with the Ministry of Religious Affairs in Bandung, and MUI in Bandung, this is carried out periodically and regularly. Then with local clerical figures, namely the Sukamiskin pesantren's leadership in developing da'wah about worship and children's morals.
\end{abstract}

Keywords : Religiosity; Youth; Da'wah.

\section{ABSTRAK}

Tujuan penelitian ini, pertama untuk mendapartkan data empirik tingkat religiusitas remaja warga binaan di Rutan LPKA Kelas II Sukamiskin Bandung. Kedua untuk mendapatkan data tentang pengembangan dakwah dan pebinaan keagamaan terhadap remaja warga Binaan di Rutan LPKA kelas II Sukamiskin Bandung. Penelitian ini menggunakan Metode Research and Development (R\&D) atau penelitian dan pengembangan dengan pendekatan kualitatif. Hasil penelitian menunjukan bahwa, religiusitas warga binaan di Rutan LPKA dikatagorikan menjadi tiga yaitu: tingkat keagamaan sangat baik, cukup baik dan kurang, dari tiga katagori tersebut ditentukan program dakwah dan pembinaan kegamaan di Rutan remaja LPKA Sukamiskin Bandung. Pengembangan dakwah dan pola pembinaan keagamaan terhadap remaja warga binaan di Rutan LPKA kelas II Sukamisnin Bandung dilaksanakan dengan melibatkan berbagai pihak. Secara kelembagaan bekerja sama dengan Kementrian Agama kota Bandung, dan MUI kota Bandung, dilaksanakan secara periodik dan terjadwal. Kemudian dengan tokoh ulama setempat yakni pimpinan pesantren Sukamiskin dalam pengembangan dakwah tentang ibadah dan akhlak anak.

Kata kunci : Religiusitas, anak remaja, dakwah. 


\section{INTRODUCTION}

This research originated from the concern regarding the moral decadence of a group of teenagers today who have deviated far from religious teachings' values and norms. Aroma, I. S., \& Suminar, D.R. (2012: 2), according to him that "violations committed by teenagers today, are not only criminal acts, but also other violations such as running from home, skipping school for drinking alcohol." In line with that, Hamzah, A \& Prahesti (2002: 78), Research and Development Center of the Indonesian Ministry of Social Affairs, the results of their research show that emotion and adolescence are triggers of delinquency. This form of juvenile delinquency is the failure of adolescents to fulfill their developmental tasks. On the other hand, adolescents' success in fulfilling developmental tasks encourages adolescents to be aware of and sensitive to the prevailing values and norms. Then they can refrain from encouraging selffulfillment so as not to violate religious teachings, norms, and rules that apply in society. These are when our teens are vulnerable and tend to break the rules and even commit criminal acts.

Based on statistical data, the number of adolescents between the ages of 15 and 19 years, to be precise in 2005 reached 20,329,857 people. This number is quite significant because it is in third place after the 5-9 years and 10-14 years age groups. (Indonesian statistics in 2008). As we know that at this age, our teenage years are very vulnerable to the consequences of promiscuity and the swift flow of globalization with all advances in information and communication technology. There have been quite a number of our teenagers as the nation's next-generation who have become victims of drugs, prostitution, brawl, alcoholic drinks, and deviant behavior, which eventually face the law that ends up in prison as inmates of the Penitentiary Penitentiary.

According to Sofyan (2013), in Kompas.com. Juvenile delinquency is increasingly worrying, with the number of deviant behavior committed by our adolescents, it is at the level of a criminal problem because the level of delinquency committed by adolescents is beyond normal limits. According to Hurlock (2002), he explains that several things can affect emotional maturity, namely that his social environment can provide a safe, comfortable, and open atmosphere in his social relationships. Give space and time to discuss various personal problems with others. Exercise channeling physical play or work can actualize his habit of understanding and mastering his emotions and passions. These are when our vulnerable youth need guidance and an appropriate approach by the conditions of these youth.

Therefore, the roles and functions of detention centers for adolescents and children must be designed so that adolescents and children, while in detention, receive guidance and guidance by their needs, deliver adolescents and later become functional members of society. In handling children who have 
been sentenced to imprisonment, adolescents still have the right to receive coaching, guidance, supervision, assistance, education, training, and other rights by the provisions of the prevailing laws and regulations. The juvenile prisons are then obliged to provide education, skills training, coaching, and fulfillment of other rights by the provisions of laws and regulations. Class II Sukamiskin Bandung Child Special Guidance Institution (LPKA) is one of Indonesia's correctional institutions as a detention center that accommodates adolescents and children who are either in the trial process or whose verdicts have been determined as income.

In the Class II LPKA Prison in Sukamiskin Bandung, 192 youth were assisted, members. The number of adolescents caught in legal problems fluctuates in nature, usually due to brawls between teenagers or students, which have recently occurred, especially in big cities such as Bandung and other cities in Indonesia. Wadong explained, M.W. (2000), "When the legal process is ongoing and become a member of the detention center, usually there is regret that they always arrive late because they begin to feel, especially when the inmates have just entered the detention center, the atmosphere that is awakened in the detention center is very different from what has been experienced outside the detention center." They begin to feel distant from their parents, siblings, relatives, and friends who can no longer be together. For adolescents who are caught in legal problems both in the trial process and in the legal verdict with permanent force, they usually have to wait for the next time to pray and submit. So this is where the emergence of teenagers' religious attitudes of religiosity while serving as residents of detention centers (Rutan).

Some of the research results related to religiosity, among others, are the research results by Hani Herlina and Aceng Kosasih (2008), entitled "Prevention of Delinquency in Daaruttauhid Junior High School, Boarding School. The research aims to determine the preventive and repressive measures carried out by boarding schools in overcoming juvenile delinquency. In this study, they were using a qualitative approach and a case study method. In comparison, the data collection technique is done by using observation, interview, and documentation study. The research informants consisted of the school, the students, and the surrounding community. His research results indicate that preventive and repressive measures in tackling juvenile delinquency by boarding schools are carried out by maximizing the preaching and role of Islamic education.

Then Luluk Wulandari (2019), in the research title "The Effect of Relativity on the Moral Development of Middle School Students," in the Proceedings of the National Seminar \& Call Paper 158, the 2019 Faculty of Educational Psychology. The research objective was to determine how big the relationship between religiosity and moral development in high school students (SMA). This research uses quantitative methods-accidental sampling data collection technique. The data analysis technique used a regression test. The 
results of this study found the influence of religiosity on children's moral development.

Juli Aridhona (2018), in her research entitled "The Relationship of Personal and Moral Behavior with Religiosity in Adolescents," the purpose of this study was to determine the relationship between prosocial behavior and religiosity with morale in adolescents. This study used 100 teenagers in junior high school, aged 13 to 16 years. His research results indicate that there is a significant relationship in prosocial behavior and religiosity with morale in adolescents.

This study shows that there is a dimension of religiosity that is highest among adolescents in Yogyakarta, namely the dimension of ritual. The research method used is two approaches, namely: quantitative and qualitative approaches. The quantitative approach is carried out using a Religiosity scale (Tina Afiatin, 1998: 55).

Annisa Fitriani, (2016) The research entitled "The Role of Religiosity in Improving Psychological Well Being," her research describes religiosity and an overview of enhancing Psychological Well Being. Based on the results of the study, it shows that religiosity plays an essential role in improving children's psychological well being.

Vidya Tweriza Nuandri, and Iwan Wahyu Hidayat (2014), in this study, aimed to determine the relationship between attitudes towards religiosity with attitudes towards the tendency of premarital sex behavior in late adolescents who are dating at Airlangga University, Surabaya. The research method used was the sampling technique. These results indicated a significant negative relationship between attitudes towards the tendency of premarital sex behavior with attitudes towards religiosity in late adolescents who were dating at Airlangga University, Surabaya.

Based on the description above, it shows that every teenager has a different level of religiosity and is greatly influenced by various dimensions that exist around the child himself, including the background and environmental factors of a child being raised. The meaning of religiosity is expressed by the knowledge and experience he has acquired so far. Religiosity is a religious attitude because there is consistency between self-belief in religion as a cognitive element, feelings towards religion as an active element, and behavior towards religion as a conative element. When faced with a natural relationship, the growth of religious attitudes, including the assisted residents when they were in LPKA class II Sukamiskin Bandung, it is a religious attitude that appears in a member of the assisted community that will encourage him to behave by the level of obedience of each individual to his religion. Therefore, of course, many factors can influence a person's level of religiosity.

The research objective was divided into two: to get an overview of the 
patterns of handling of the assisted residents in LPKA class II Sukamiskin Bandung. The second is to obtain empirical data on adolescent assisted residents' religiosity classification in LPKA Class II Sukamisnkin Bandung.

The research method used is "Research and Development (R\&D)" or research and development from Borg \& Gall (1983: 23), which is further simplified through a preliminary study, including; literature study, field survey and field conditions, then the development of da'wah and patterns of religious development, and validation.

The difference with previous studies, first: from the five previous studies all used quantitative research, while this study used R\&D. Second, previous research is based on the perspective of education, psychology, and law. In comparison, this research is a da'wah approach and a religious guidance system in class II Rutan LPKA Sukamiskin Bandung. Third, the research's time and place were 2008-2019, while this research was conducted in 2020.

The impact of this research is to become one of the references and references in policymaking to develop dakwah and religious guidance for adolescents during detention by existing situations and conditions. This research is a preliminary description of adolescent religiosity and da'wah's development with methods and approaches for adolescents in Ruah Prisoners (Rutan).

\section{RESULTS AND DISCUSSION}

\section{The Religiosity of the Assisted Youth in the Class II Rutan LPKA Sukamiskin Bandung}

The number of adolescents assisted by prisoners in LPKA class II Sukamiskin is 192 (and ninety-two) people, where overall when they first entered the remand center they had a religious or religious attitude that tended to be weak or lacking good religious attitudes, even though some of them had religious knowledge is quite good. However, the influence of their lousy association while outside of detention is not right, and they eventually fall into acts that violate the law, which eventually enter the detention center. Based on these conditions, one of the class II Sikamiskin LPAK programs is developing dakwah, and religious guidance carried out for teenage prisoners while in detention. This activity involves various parties, both prison officers themselves and from outside the prison.

From inside the prison are guards who specifically have functional religious abilities and are specifically assigned to carry out da'wah activities by giving religious lectures or scheduled recitation activities. From outside the prison, the LPKA collaborates with the Ministry of Religion of the city of Bandung, the local MUI as well as several religious organizations and several community leaders and involves several religious leaders, such as the Sukamiskin Bandung Islamic boarding school because of its relative location to the 
Sukabmiskin LPKA Class II Prison.

The vision carried by LPKA Kalas II Sukamiskin Bandung City is to restore the inner life of adolescents as good individuals and members of society and always carry out their duties and obligations as creatures created by God Almighty so that in turn the LPKA Prison is a proud person in providing services and guidance to assist residents who are equipped with faith, knowledge and various practices that must be carried out as assisted citizens in a correctional institution.

Aviyah, E and Farid, M (2014: 126) Persona, Indonesian Journal of Psychology Religiosity, Self-Control, and Juvenile Delinquency, revealed that the form of juvenile delinquency is indicated because they lack a level of religiosity and low self-control and these are two things, which are related. Erike Anggraini (2005: 39) explains that a person's daily behavior can affect the way and work ethic of a person, so there needs to be an approach and guidance as early as possible so that everyone can make an orderly and orderly life habit". So in this detention center, it can become one of the "role models" so that good patterns and habituation can become provisions for society's life.

According to Mira Fauziah (2013), religion is a human acknowledgment of the existence of magical powers outside of him, and humans have a relationship with these supernatural powers, then that magical power controls influence human actions. The unseen thing in Islam is the belief in Allah SWT. To increase religiosity's attitude, later on, adolescents need to learn and listen to Islamic preaching. So religious guidance for adolescents is carried out through preventive and repressive measures to overcome this by maximizing Islamic education. It is one of the alternatives to improve adolescent religiosity attitudes in detention centers.

Religiosity is closely related to a human being's inner life, which is one way in the process of getting closer to God. Of course, many factors can affect a person's level of religiosity. Likewise, the assisted residents in LPKA class II Sukamiskin Bandung have different religious backgrounds. The growth of religious attitudes when this is faced with a natural relationship by every individual, including the assisted residents, when they are in LPKA class II Sukamiskin Bandung. The religious attitude in a member of the assisted community will encourage him to behave by the level of obedience of each individual to his religion.

The religiosity or religious attitudes of adolescent residents of detention centers are determined by their respective religious backgrounds, such as to what extent a child learns about religion and their daily social environment. The attitude of religiosity will also determine the child's ability to understand and interpret the religion they profess. Even so, other factors will influence the child himself, including the factor of "guidance," which is the awareness of the 
adolescents themselves in understanding, interpreting, and implementing the teachings of their religion.

The implementation of religious activities in LPKA class II Sukamiskin Bandung by providing representative facilities by the assisted residents' needs in children's prisons. The time, place, and schedule have been carefully prepared by involving various parties. The implementation of religious activities at the remand center is part of daily activities that are inseparable from the pattern of coaching young inmates held in LPKA class II Sukamiskin Bandung. The religiosity of a teenager in the detention center will be seen in everyday life, especially in religious practice, especially the level of religiosity is one of the benchmarks for a teenager to become a prison member in the LPKA Kals II Sukamiskin Bandung detention center.

Based on the research findings, it shows that there are three levels of religiosity of the members of LPKA Sukamiskin guidance that can be classified into three groups. First, the assisted residents who have an excellent level of religiosity. Namely, the inmates who regret all their work and have a good background in religious abilities. Those who belong to this first classification are 31 (three pulu) people. The second is the assisted residents who have a "good enough" level of religiosity. They are sorry for their practices to become residents of the assisted residents, but they do not have functional religious abilities. Those who belong to this second classification are about 79 people, and.

The third is that they tend not to show a sense of regret for their activities. At the same time, being assisted members of LPKA and do not have the ability and proper background of understanding religion as many as 6 (six) people, these are the ones who need intensive religious guidance, the prison maximizes individual guidance well carried out by prison officers or accurately carried out by religious, spiritual guidance (warois). The development of Islamic da'wah and religious guidance for young people assisted by LPKA must be comprehensive by involving various parties, including their parents.

Furthermore, the religiosity of adolescent members of the detention center in LPKA class II Sukamiskin Bandung city. However, it must be admitted that the factors that influence the religiosity of a child of assisted residents in LPKA Sukamiskin, among others, are background and learning experiences related to their religion. However, based on the research results, it shows as follows: First, assisted residents to have a high religiosity level. They are inmates who regret all their clothes, and they are friendly in their way and have a good background of religious ability. Those who belong to this first classification are 15 (fifteen) people. The second is the assisted citizens who have a "moderate" level of religiosity. They regret their practice so that they become residents of the assisted residents, but they do not have excellent religious abilities. Those who belong to this second classification are about 45 people, and. Third, they tend to 
show less remorse for their actions while being assisted members of the LPKA and do not have the ability and background and good religious understanding. Those who belong to the third classification, namely "less," are only 132 (one hundred thirty-two) people in number. Based on these data, it shows that the average level of adolescent religiosity tends to be low, so there needs to be a development of da'wah and religious guidance specific to adolescent members of the assisted youth in LPKA Sukamiskin Bandung.

Religious background, experience, and abilities related to religious teachings are one of the fundamental factors that a child of assisted residents has a certain level of religiosity. Therefore, fostering religious teachings is an essential factor for anyone in shaping a sense and attitude of awareness of religious teachings. All of our actions and goals are coherent because having more than one ultimate goal will prevent our capabilities from becoming various parts and certainly hinder success. Even according to Nisya, S, L \& Sofiah, D (2012: 562) explains that "the level of religiosity of a child is one form of intelligence that can prevent delinquency behavior."

In line with the above explanation, according to Zaenab Pontoh M. and Farid (2016, 100-110), the results of their research show that there is no relationship between social support and the happiness of religious converts. If we pay attention to one's religiosity level, it does not become a measuring tool because of one's happiness because, in religion, happiness is owned by someone who has the right level of faith in Allah SWT. Another finding in this study, several factors influence religiosity, namely the background of the influence of education or teaching and various social pressures (social factors) which include all social influences in the development of religious attitudes, including parental education, social traditions to adapt to various income attitudes agreed upon by the environment.

\section{The Development of Da'wah and Religious Guidance for Youth of Assisted Citizens in Class II Rutan LPKA Sukamiskin Bandung}

LPKA class II Sukamiskin Bandung is a detention house (Rutan) for adolescents or children who are currently litigating with legal issues, both those who are still in court proceedings and convictions that have reneged on legal decisions in court. Technically, LPKA class II Sukamiskin is a technical implementation unit under the Directorate General of Corrections at the Ministry of Law and Human Rights.

Several terms have been developed for Penitentiary inmates' titles, which can be called prisoners (inmates) or Penitentiary (WBP) whose status is a prisoner whose legal status is still in the court process, which has not been determined guilty or not by the court.

During the detention period, the young inmates will receive guidance and 
services from prison officers called wardens. They are civil servants assigned to guard and serve prisoners during their detention. The task of the prison position is not only to carry out the punishment but has a broader task which is to restore the morals, mentality, and behavior of adolescents while in detention so that they can return or re-integrate into good society. So that one of the programs in prison is to conduct preaching and religious guidance for adolescents while in detention. Therefore, the religious atmosphere while in detention is one of the religious programs so that teenagers, while in detention, have good religiosity, resulting in a strong mentality and behavior by the values and norms prevailing in the society.

According to Al-Maududi, A, A. (1994: 1), in research relating religiosity with coping behavior, it was determining whether religiosity causes certain coping behaviors, namely ripe or immature. The research was conducted on students of the Faculty of Psychology UMS class of 1995/1996. The results showed that high levels of religiosity tended to show mature coping behavior, and those with low levels of religiosity showed immature coping behavior.

LPKA Class II Sukamiskin Bandung. The aim is to guide the adolescents of the assisted residents while in detention to become complete adolescents as complete adolescent individuals, who are aware of the mistakes they have been doing so far. Furthermore, while in the remand center, teenagers improve themselves so that they do not repeat the same actions so that in the end, they will be accepted back into good society. Besides, the prison continues to provide guarantees and full protection for teenagers in detention during their detention. One of them is to guarantee the safety and security of objects confiscated for the benefit of evidence at the level of investigation, prosecution, and examination at court proceedings and other objects secured for the state based on court decisions.

The number of deaths, illnesses, and treatment costs is the same as the minimum needs of the Indonesian people. Therefore, the conditions of detention must always be maintained, tidy, clean. Safe and in a healthy state. As the Word of Allah SW'T, in the Al-Qur'an (2010). Tafsir and Word Translation, Al-Jabal, Ministry of Religion of the Republic of Indonesia. Jakarta, which means: "O you who believe, protect yourself and your family from the fires of hell, whose fuel is humans and stones; the keeper of the angels who are harsh, harsh, and obeys Allah against what He commands them and always do what is ordered. (Al-Qur'an, Surat At-Tahrîm, 66: 6). Furthermore, Rohimi (2019: 137), in his research, revealed that an ethical approach or religiosity could solve juvenile delinquency behavior according to the atmosphere and spirituality faced by adolescents.

Based on the verse above, it shows us that Allah SWT commands believers always to protect themselves and their families from hellfire. From this verse, it becomes a reminder to every Muslim and Muslim who believes that the 
measure of humans' happiness and success who believe in the hereafter will enter the Heaven of Allah SWT. Even in one narration, Ibn Abbas RA once said that the meaning of "guard yourself and your family from the fire of hell," is all that we will do only in order to obey Allah SWT, as well as our courage to leave disobedience as a whole and order them. To dhikr to Allah SWT. So when our teenagers are in detention, the approach of preaching and religious guidance becomes a complete unit as a family of assisted residents so that later they leave the detention center to become useful members of society and be accepted back as members of the community.

The existence of youth while in prison will be related to the condition of facilities and infrastructure as support. Correctional facilities and infrastructure according to Law No. 12 of 1995 concerning correctional facilities as stipulated in article 3 and directed to support the pattern of fostering the situation and condition of adolescents during detention, where all teenagers who become residents when they first enter detention tend to have problems with a variety of religious backgrounds for each teenager, among other things: unstable religious backgrounds, weak spiritual mentality, and uncontrolled behavior patterns, and their quality of health that is less vulnerable. It is a consideration for the facilities and infrastructure of LPKA to support the implementation of pattern guidance while in the detention center. Besides, the existing facilities and infrastructure are directed at increasing social and national resilience as an important indicator used to measure how much the results can be achieved during the coaching process at adolescent remand centers while in remand center.

The various kinds of legal cases that ensnare teenagers are usually very diverse, and the number fluctuates depending on the background and the problems they face, these cases include brawls involving large crowds, drug cases, and other criminal cases. While in prison, adolescents' mental attitude is continuously awakened to build a positive attitude for their better future, they must realize that as the nation's next-generation, a balance must be realized, to look at the progress of youth in the future. Likewise, in the cognitive, affective, and psychomotor aspects, it is still directed as individual family members, community members, and at the same time as creatures created by Allah SWT. To restore the quality of the relationship between adolescents of detention centers with their families and communities through social reintegration efforts are carried out gradually and continue to realize the best interests of children, protection, justice, non-discrimination, and respect for children's opinions.

In the implementation of services, care, education, guidance, guidance, and assistance in children's development and growth, always consider the aspects of child psychology handled by experts. Then in terms of faith and piety, intelligence, politeness and joy of children so that they can become independent and responsible human beings, assistance is also carried out, so that LPKA 
institutions are appropriate and child-friendly, and can prepare youth prisons to have the ability to play an active role in development after they return to society. Besides that, there are several keys in the pattern of handling student peseta, namely: Religious, Moral, independent, safe, and humanist, who are always maintained in an intimate and kinship atmosphere.

Based on the research results, the handling pattern of adolescent assisted residents in LPKA class II Sukamiskin is already very good with a nurturing and serving parenting system, even the pattern of handling assisted youths positions the assisted youth as students, the same as the pattern implemented in schools. In general. Handlers in the education sector, LPKA class II Sukamiskin collaborated with the Bandung City Education Office. In class II, LPKA Rutan Sukamiskin Bandung did not carry out formal education directly, but the implementation of formal education was left to existing educational institutions, but the remand center only provided time and space in the remand center. The implementation of education for the junior high school level is handled directly by SMPN 8 Ujungberung Bandung as the primary school in East Bandung, where teachers directly carry out Teaching and Learning Activities (KBM) at the LPKA detention center that has been provided. For the SLA level, the party cooperates with the SKMN in Gedebage Bandung and one of the very vocational schools in the East Bandung area.

\section{The standard of service is through preaching and fostering the diversity of adolescents in the LPKA class II Sukamiskin Bandung city}

The findings of adolescent religiosity research show that religious education's role and function in shaping adolescent personality is in the category of Less. One of the factors is the effectiveness of learning through the development of Islamic da'wah. Therefore, it is necessary to optimize the development of da'wah that is more effective and attractive for the adolescents who are assisted in the Rutan LPKA Sukamiskin Bandung. The results showed that the dakwah and religious development system was carried out in an integrated manner which was implemented in the mosque and the skill room using the assistance method (regeneration) which focused on Fiqh on the procedures for praying and reading and writing the Qur'an (BTQ) separately between male and female prisoners. The role of religious organizations (Wahdah) and community-assisted prisons (WBP) dramatically helps the prison/remand center contribute to spiritual development. On the other hand, the optimization of religious guidance has not been maximized, because the synergy between the Menkumham and the Ministry of Religion (religious extension) has been in a vacuum since last year.

Prison managers (supervisors) and remand centers have limitations in implementing religious guidance, among others, the ratio between coaches/mentors and prisoners is not balanced, coaching is carried out naturally, 
knowledge of prison managers (supervisors) about knowledge of Islam is actualized based on experience, lack of support media and facilities (religious books and rooms) for guidance can cooperate with a mobile library or a library in the nearest area, and the schedule of coaching activities can be more intensified.

The development of da'wah and guidance for assisted residents is carried out comprehensively by involving various related elements, both government officials, law enforcers, and community leaders to get used to living peacefully and peacefully in doing everything by the applicable legal rules in society, by looking at the side individual psychology of the perpetrator, the family, community, and society at large. The approach pattern of preaching and religious guidance to the assisted citizens in LPKA already has a standard as a regulation set by the Ministry of Law and Human Rights, including Number 11 of 2012 concerning the Juvenile Criminal Justice System now on referred to as the SPPA Law. SPPA Law, Law No. 3/1997 on Juvenile Courts (Juvenile Court Law). As in the Convention on the Rights of the Child (Convention on the Rights of the Child) regulates legal protection for children to provide exceptional protection for children who come into contact with the law, by applicable laws and regulations. Regulation of the Minister of State for Women's Empowerment and Child Protection Number 15 of 2010 concerning General Guidelines for Handling Children in Conflict with the Law. What is further regulated in the Arcamanik charter, which contains ten principles for handling child development in LPKA, as regulated in Law Number 12 of 1995 concerning Corrections, in which young people assisted in detention are referred to as correctional students.

In-Law Number 23 of 2002 shows that the state must indeed guarantee the welfare of every citizen, including protecting the rights of our children and adolescents as an inseparable part of human rights, in which every child or teenager always attached to dignity as a whole and real human being. Besides, every child or teenager must be positioned as a movement to continue the ideals of the Indonesian nation's struggle in the future, which has a very strategic role and has distinctive characteristics and characteristics in ensuring the continuity of the existence of this nation and state for the future so that every child or adolescents will be able and responsible for the future of the Indonesian nation. In line with the above opinion, according to Tedy Sudrajat (2011, 119-120) explains that "every child or adolescent needs to have the same and the most comprehensive opportunity to grow and develop optimally, both physically, mentally and socially, while maintaining good morals. Noble. There needs to be a protection effort to realize the welfare of children and adolescents by providing guarantees for the fulfillment of their rights and treatment without any discrimination. 
According to Unayah and Sabarian (2015), stating that in dealing with juvenile delinquency problems, it is necessary integrated cooperation of various related elements, both government, law enforcement officials and figures society creates a habit of living peacefully and peacefully by the values and norms prevailing in the society.

Based on the description above. That the pattern and handling of assisted residents in LPKA class II Sukamiskin Bandung always refer to the Standard Operating Procedure (SOP) set a standard, making it easier for LPKA managers and officers to carry out their daily duties. It is because it already has SOPs and regulations so that, in turn, it will make it easier to conduct evaluations. According to Hikmat (2010: 61), that "the management process in an institution or institution, a rule is needed which is made as a collective agreement, it will make it easier for the institution to evaluate a goal to determine whether the program is successful or not". In line with that, according to Hikmat (2020: 216), in his book Industrial Sociology, describes that "The service process in the global era has now achieved to become an industrial service provider requiring competitive, professional and independent handlers.

The management and management process in prisons, in the program presentation, pays attention to the rights of teenage prisoners or their assisted citizens to have the right to receive proper treatment as part of the family. Maria Ulfah (2007) The results of his research explain that "family harmony and selfconcept together play a role in juvenile delinquency tendencies." In physical care, providing opportunities for sports and recreation, getting clothing equipment, and the right to get sleeping and bathing equipment, spiritual care is given through spiritual guidance and character education. Besides, residents of the remand center are entitled to receive education and instruction until they have a Certificate of Completion of Study (STTB) from the competent authority if they have completed education and teaching. Then get proper health services, among others, get health services, then get food and drink by the number of calories that meet the health requirements with a perfect healthy five-pole and additional according to the doctor's instructions for adolescent members of the assisted residents while in prison.

Likewise, prison residents have the right to submit direct complaints to the head of the prison if there is the treatment of officers or fellow residents; besides that, they are entitled to receive wages or premiums by the laws and regulations that apply to all activities that generate profits. The assisted residents can receive visits from family, legal counsel, or certain other people. Referring to the results of Susanti's research, R (2017) explains that "the pattern of preaching and religious guidance for criminals, especially in the development of the Islamic religion, besides being carried out by prison officials, also collaborates with the Regency Ministry of Religion, especially in joint recitation activities, recitation and reading and writing of the Qur'an. 'an as well as strengthening and prayer 
procedures ".

Based on the findings of the research, it shows that the development of da'wah and religious guidance for adolescents at the LPKA Sukamiskin Bandung Prison is strengthening and fostering of Islam through a taklim assembly organized by the inmates and detainees themselves so that with fellow prisoners they can carry out peer learning activities, give and receive, for those who have good religious knowledge can become prayer leaders, give lectures and teach reading and writing the Qur'an. Meanwhile, others can learn. Da'wah activities and religious guidance such as this can be used as a model and reference for other detention centers according to the situation and conditions.

Muhtar Hadi (2017), in his research on High School Youth Religiosity, Metro Lampung, Dalam TAPIS, Vol. 01, No. 02 July- December 2017 IAIN Lampung. He was explaining that "The approach of preaching and religious guidance to adolescents today is more directed at approaches relevant to the needs of adolescents. The da'wah approach for adolescents, among others, is carried out with the principle of coaching, children as a mandate from Allah SW'T need to be guarded and nurtured, they as the nation's next-generation must have the widest possible opportunity to grow and develop optimally".

According to Fatchurahman and Pratikto (2012), "During the process of detention and imprisonment for children is the last resort and is carried out the shortest by taking into account the best interests of young children." The purpose of prison development is a system of guidance and guidance, in which children must receive character-based restorative justice. Giving imprisonment is not a form of revenge from the State. Therefore, the dignity of an individual must still be respected. While in LPKA youths continue to carry out coaching and guidance, they should not be isolated from their families and communities. Likewise, in fostering and guiding children, they are entitled to protection from violence and all other forms of discrimination by human dignity, in terms of education as the essence of coaching and guidance for children to improve intellectual, emotional, and spiritual intelligence, and develop children's potential and skills training in developing interests and talents according to their choice.

The coaching and mentoring pattern for the assisted youths must be directed to return to the family and community as soon as possible in the form of the Assimilation and Reintegration program so that later they are ready to become functional members of society. Furthermore, the state, in this case, guarantees the protection and fulfillment of the rights of adolescent prisoners in prison through the provision of child-friendly resources and infrastructure; furthermore, the dakwah approach and religious guidance and guidance for children are carried out synergistically between the caregivers of the community counselors, families and communities. In line with the explanation above, several factors can influence the development of a person's religiosity, that the factors 
that can influence religiosity are the influence of education or teaching and various social pressures (social factors).

Social factors in religion consist of various influences on religious beliefs and behavior, from the education we received in childhood, the various opinions and attitudes of the people around us, and the various traditions we received from the past. Various experiences help religious attitudes, especially experiences about beauty, harmony, and goodness in other worlds (natural factors). On the other hand, this experience is meant as a natural factor whereby a person can realize that everything in this world is because of Allah SWT.

\section{CONCLUSION}

There are two significant findings from the findings of this study: First, the research findings show that the level of religiosity of youth in the LPKA Sukamiskin target is divided into three categories, namely: good religious ability and carry out Islamic teaching well too. The third category is good enough as many as 45 (forty-five) people; they have a pretty good knowledge of Islam and do it pretty well. Moreover, the third category is less, as many as 132 (one hundred and thirty-two) people lack knowledge of Islamic teachings and lack in practicing religion. The difference in the level of religiosity of the assisted residents is influenced by the background, experience, understanding, and religious ability from outside the detention center. Based on these data, it shows that the level of religiosity of adolescent detention is, on average, lacking, so it is necessary to develop dakwah by the needs of youth in LPKA Sukamiskin Bandung.

Second, that the implementation of the development of da'wah and fostering of the Islamic religion for adolescent members of the assisted community in the LPKA Prison Class II Sukamiskin Bandung was carried out in a planned, integrated manner. Directed and on an ongoing basis by involving various elements, including the Ministry of Religion of the City of Bandung, and MUI Sukamiskin as well as several local ulama figures, namely the leadership of the Sukamiskin pesantren, especially in the development of Islamic da'wah, especially guidance and guidance related to aqidah, worship, shari'ah and the morals needed for adolescent members of the assisted community at the Sukamiskin LPKA Prison in Bandung. This study's findings indicate that there is a very significant change in the religiosity of adolescent prisoners in detention, especially in understanding aqidah, shari'ah, and moral behavior and their worship. In contrast, in the detention center, which is getting better, this can be seen especially in carrying out worship. The five daily prayers are carried out in congregational mosques in an orderly manner, and young prisoners have a better and more stable mental attitude because of the better level of religiosity. As mentioned above, the two findings of this research, between the level of 
adolescent religiosity and the development of da'wah, are two essential things that cannot be separated as the findings of the research conducted at LPKA Sukamiskin Bandung.

\section{REFERENCE}

Al-Maududi, A.A. (1994). Dasar-dasar Islam. (Terjemahan M. Achsin). Bandung: Gramedia.

Al-Qur'an, (2010), At-Tahrîm/66:6, Tafsir dan Terjemahan Perkata, Al-Jabal, Kementrian Agama RI. Jakarta. https://almanhaj.or.id/4126-jagalahdirimu-dan-keluargamu-dari-api-neraka.html

Aridhona, J. (2018) Hubungan Prilaku Prososial Religiusitas Dengan Moral Para Remaja, Jurnal Vol 7 no 1, Universitas Mubamdiyah Malang Indonesia.

Aroma, I. S., \& Suminar, D.R. (2012). Hubungan antara tingkat kontrol diri dengan kecenderungan perilaku kenakalan remaja, Jurnal Psikologi Pendidikan dan Perkembangan,1(2),1-6.

Aviyah, E., \& Farid, M. (2014) Religiusitas, kontrol diri dan kenakalan remaja. Persona, Jurnal Psikologi Indonesia 3(2), 126-129.

Balai Penelitan dan Pengembangan (Balitbang) Departemen Sosial RI, (2008), $\begin{array}{lllll}\text { diakses } & \text { tanggal } & 17 & \text { Juli } & 2020 .\end{array}$ 11.https://www.bps.go.id/publication/2008/08/15/5949f69e03fcdd59df c96edf/data-strategis-bps-2008. html.

Borg And Gall, Meredith Damien, (1989) Educational research and development is a process used to develop and validate educational product, New York: Longman.

Fatchurahman, M., \&Pratikto, H. (2012). Kepercayaan diri, kematangan emosi, pola asuh orang tua demokratis dan kenakalan remaja. Persona: Jurnal Psikologi Indonesia, 1(2), 77-87.

Fauziah, M. (2013). Metode Dakwah Dalam Membangun Religiusitas Masyarakat, Jurnal Al-Bayan, 19(28).

Fitriani, A. (2016). Peran Religiusitas Dalam Meningkatkan Psycological Well Being, Al-Adyan, 11(1).

Hadi, M. (2017). Religiusitas Remaja SMA (Analisis Terhadap Fungsi dan Peran Pendidikan Agama Islam dalam Membentuk Kepribadian Siswa), TAPIS, 1(2).

Hamzah, A. (2002). Pengaruh Komunikasi Keluarga Terhadap Kenakalan Remaja, Undergraduate Theses from JIPTUMM. http:/ / digilib.itb.ac.id/gdl.php?Mod=browse\&op=read\&id=jiptumm-gdls1-2002- arief-4878-komunikasi\&q=Remaja. Diakses 21 Juli 2020.

Herlina, H., \& Kosasih, A. (2018). Penanggulangan Kenakalan remaja SMP Daarutahuid Bording school. Jurnal Societas, 5(2).

Hikmat. (2010). Manajemen Pendidikan. Bandung: Pustaka Setia.

Hikmat. (2020). Sosiologi Industri, Edisi Pertama. Bandung: Penerbit Agung Ilmu. 
Hurlock, E. B. (2002). Psikologi Perkembangan: Suatu Pendekatan Sepanjang Rentang Kehidupan. (Alih Bahasa : Istiwidiyanti dan Soedjarwo). Jakarta : Airlangga.

M. Pantoh Z \& Farid, (2016). Hubungan Antara Religiusitas dan Dukungan Sosial dengan Kebahagiaan Pelaku Konversi Agama, Persona Jurnal Psikologi Indonesia, 4(1).

Maria, U. (2007). Peran persepsi keharmonisan keluarga dan konsep diri terhadap kecenderungan kenakalan remaja (Doctoral dissertation, Universitas Gadjah Mada).

Nisya, S. L., \& Sofiah, D. (2012). Religiusitas Kecerdasan dan kenakalan Remaja, Jurnal Psikologi, 7(2), 562-584.

Nuandri, V. T., \& Hidayat I. W. (2014). Hubungan Antara Sikap terhadap Religiusitas dengan Sikap terhadap Kecenderungan Perilaku Seks Pranikah pada Remaja Akhir yang Sedang Berpacaran di Universitas Airlangga Surabaya, Jurnal Psikologi Kepribadian dan Sosial, 3(2).

Rohimi. (2019). Hipnoterapi: Proses dan Dampak Religiulitas dalam Menyelesaikan Kasus Kenakalan Seorang Remaja, Jurnal Ilmiah SYIAR, $\begin{array}{lll}\text { Jurusan } & \text { Dakwah, 19(2), }\end{array}$ https://ejournal.iainbengkulu.ac.id/index.php/syiar Vol. 19, No. 02, Desember 2019; hlm. 127-137.

Sofyan, E. H. (2013). Kompas Cyber. Kenakalan Remaja Makin Mencemaskan,KOMPAS.com.https://megapolitan.kompas.com/read/20 13/10/08/0920254/Kenakalan.Remaja.Makin.Mencemaskan Diunduh $05 / 05 / 2019$.

Sudrajat, T. (2011). Perlindungan Hukum Terhadap Hak Anak Sebagai Hak Asasi Manusia, Kanun Jurnal Ilmu Hukum, 13(54), 111-132.

Susanti, R. (2017). Penguatan model Pembinaan Kegamaan Islam bagi Nap dan Tahanan di Di Rutam Banyumas, Fakultas Hukum Universitas Muhammadiyah Purwokerto, Jurnal Kosmik Hukum, 17(2).

Unayah, N., \& Sabarisman, M. (2016). Fenomena Kenakalan Remaja dan Kriminalitas, Sosio informa, 1(2).

Undang-Undang Nomor 11 tahun 2012 tentang Sistem Peradilan Pidana Anak mencabut Undang-Undang Nomor 3 Tahun 1997 tentang Pengadilan Anak (Lembaran Negara Republik Indonesia Tahun 1997 Nomor 3, Tambahan Lembaran Negara Republik Indonesia Nomor 3668) https://www.jogloabang.com/sites/default/files/dokumen/uu11_th_201

2-sistem-peradilan-pidana-anak.pdf diakses tanggal 20 Juli 2020

Wadong, M. W. (2000). Pengantar Advokasi dan Perlindungan Anak. Jakarta: PT. Gramedia Widia Sarana Indoensia.

Wulandari, L. (2019). Pengaruh Religusitas Terhadap Perkembangan Moral Sisiwa Menengah Atas, Prosiding Seminar Nasional \& Call Paper 158 Psikologi Pendidikan 2019 Fakultas Pendidikan Psikologi, 13 April 201. 
Hikmat Hikmat1 